\title{
Life Cycle Assessment as a policy-support tool: the case of taxis in the city of Madrid
}

Michel Vedrenne*, Javier Pérez, Julio Lumbreras, María Encarnación Rodríguez

Department of Chemical \& Environmental Engineering, Technical University of Madrid, (UPM), c/ José Gutiérrez Abascal 2, 28006 Madrid, Spain.

\section{Abstract}

The objective of this paper is to highlight the potentialities of Life Cycle Assessment (LCA) as an instrument for policy-making support. To this respect, the adoption of an initiative within the Madrid Air Quality Plan (AQP) 2011-2015 regarding the substitution of diesel taxis with hybrid, natural gas and LPG alternatives was studied. Four different scenarios were elaborated, a business-as-usual scenario (BAU), the scenario of the AQP, and two extreme-situation scenarios: all-diesel (ADI) and allecologic (AEC). In order to provide realistic results, data covering 2,465 processes were collected from international, national and local sources. The vehicle use-phase was modeled by dividing the city in 14,938 roads within nine management zones. Impact characterizations were made according to the ILCD methodology, focusing only on acidification, climate change, particulate matter, photochemical ozone formation and terrestrial eutrophication. SimaPro 7.3 was used as the main tool for analysis and inventory construction. The results indicate that the shift to the ecologic alternatives produces a reduction of the relevant impacts, and especially of climate change (CC) and photochemical ozone formation (PO). For the complete life cycle, reductions of $13 \%$ in CC and 25\% were observed for AQP when contrasted with BAU (CC: 1365 Gg$_{\mathrm{CO} 2}$, PO: 
PO: 59\%), while ADI produced slight increases in impacts if compared to BAU. The analysis of the vehicle use-phase revealed that the central and highest speed zones of the city benefit from the adoption of the AQP, an issue that is related to the traffic conditions and emission factors for the different vehicle technologies. This is especially evident for zone 1 and zone 7, which witnessed reductions of 16\% in CC and 31\% in

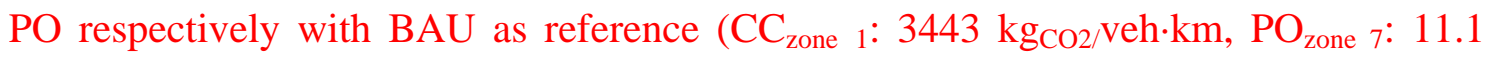
$\left.\mathrm{kg}_{\text {NMVOd}} / \mathrm{veh} \cdot \mathrm{km}\right)$. A similar behavior was observed for acidification, particulate matter and terrestrial eutrophication impacts.

Keywords: Life cycle assessment, road traffic, air pollution, decision support, policy

* Corresponding author. Tel: (+34)913363203, Fax: (+34)913363009. Email: m.vedrenne@upm.es (M. Vedrenne)

\section{Introduction}

In the last decades, LCA has been intensely used as a corporate strategic planning instrument, especially destined to promote products and services as eco-friendly. However, this trend has been seldom followed by governments, which usually concentrate actions on tackling problems at isolated life cycle stages. This is usually a consequence of the still-frequent tendency for sectoral public planning, which is reputed of being an obstacle for meeting sustainability goals (Thabrew et al., 2009).

The management of the road transportation sector at the urban level is a complex decision process with numerous implications on the local energy planning, air and acoustic pollution levels, mobility, and life quality levels. As a consequence, the quantification of its environmental impacts has been a long-standing issue in science and policy circles (Granovskii et al., 2006; Romm, 2006; DeCicco, 2013; Seckin et al., 2013). To this respect, LCA has been widely used in the evaluation of the 
environmental suitability of different transportation options, powertrains, fuels or vehicle technologies (Hackney and de Neufville, 2001; Spielmann and Althaus, 2007; van Vliet et al., 2010; Nanaki and Koroneos, 2013; Köhler et al., 2013). The extension of the same evaluation framework to taxi fleets has been already published in Mourato et al., (2004) and Baptista et al., (2011). In general, most of these studies analyzed the performance of different models of under a LCA perspective and concluded that cleaner alternatives such as hybrid, electric or gas vehicles are more sustainable than traditional fossil-fuel cars.

The main objective of this paper is to discuss the convenience of a recently-adopted environmental decision in the city of Madrid regarding the renovation of the taxi fleet. This decision was analyzed under a detailed "cradle-to-grave” perspective, using LCA as an analysis tool and focusing on the transport sector of the city as a whole. The analysis addressed in this work seeks to be more than a declaration of eco-friendliness: it intends to evaluate the effectiveness of a concrete initiative under the specific conditions of Madrid. Moreover, it seeks to provide guidance on the use of LCA for policy-support and on the suitability of referring any results to a particular reality.

\section{Case study}

The city of Madrid is currently affected by levels of $\mathrm{NO}_{2}$ which exceed the limit value laid down in EU legislation in consequence of an overwhelming road-traffic sector (Vedrenne et al., 2011; AM, 2013). As with other southern European cities, the local commitment to reduce the average $\mathrm{CO}_{2}$ emissions of vehicles in order to prevent climate change resulted in an important dieselization of the fleet, which is an additional cause of the current $\mathrm{NO}_{2}$ levels in the city (Kassomenos et al., 2006; Baptista et al., 
2012). This dieselization process was particularly evident in the taxi sector, which currently accounts for $14.8 \%$ of the local emissions of nitrogen oxides $\left(\mathrm{NO}_{\mathrm{x}}\right)$. As a consequence, the city has not been complying with the $\mathrm{NO}_{2}$ limit values specified by Directive 2008/50/EC since 2010 (EC, 2008).

In April 2012, the government of Madrid approved a series of grants to foster the incorporation of less polluting cars to the city's taxi fleet. This decision was part of an ambitious local AQP that will culminate in 2015, aimed mainly to reduce nitrogen dioxide $\left(\mathrm{NO}_{2}\right)$ levels and carbon dioxide $\left(\mathrm{CO}_{2}\right)$ emissions (AM, 2012). The fleet renovation program was included in the set of measures that the city pledged to adopt in order to obtain from the European Commission an extension in the meeting of the $\mathrm{NO}_{2}$ limits stipulated by Directive 2008/50/EC. The measure urged taxi owners to switch from diesel-fuelled cars to gasoline-hybrid, liquefied petroleum gases (LPG) or compressed natural gas (CNG) vehicles. The reception of the decision by the public was positive and towards the end of 2012, the ecologic vehicles of Toyota and SEAT accounted for almost 48\% of the total sales for the taxi sector (ANFAC, 2012).

The evaluation of this measure consisted in a LCA of the complete taxi fleet of the city of Madrid, focusing on the respective cycles of the fuel and the materials (vehicle) to further analyze the resulting effects under an impact-evaluation methodology. At this point, the consequences of the measure cannot be easily evaluated due to its recent adoption and the final outcome might be conditioned by the penetration of other technologies, price increases or by the suspension of the funding due to budget shortages. To this respect, a group of scenarios was defined assuming different hypotheses to better illustrate the effects of the measure. The characterization of the complete life cycle was carried out with detailed information, and depending on the 
stage, with information supplied directly by local authorities. In the following sections, the description of the methodology, datasets, assumptions and evaluation tools is made.

\section{Methodology and datasets}

\subsection{System definition}

The system was modeled by trying to include all the phases susceptible of being affected by the renovation of Madrid's taxi fleet (Figure 1). As it was already stated in section 2, we divided the entire life cycle of the vehicles in the following parts:

- Fuel life cycle. Composed by the following phases: (i) crude exploration and production processes, (ii) transportation to the refinery, (iii) conversion and refining, (iv) storage and transportation to the distribution centers and (v) the vehicle in-use or tank-to-wheels (TtW) phase. The first four phases are also known as the well-to-tank phase (WtT).

- Material life cycle. This comprises (i) the extraction and production of raw materials, (ii) the manufacturing of the vehicle, (iii) its transportation to the sale point and (iv) the use-phase. The end-of-life phase is not considered due to its high dependency on the actual practice in real life and because there is a limited amount of data on this phase with large variability in open literature (Ma et al., 2012).

Due to the lack of information, the building and dismantling process of the extraction, distribution, production and sales facilities as well as roads and other urban infrastructures were not considered. In the same line, vehicle and infrastructure (pumps, 
vessels, pipelines, etc.) maintenance operations, as well as the spare parts' supply chain were not taken into consideration (Garg et al., 2013).

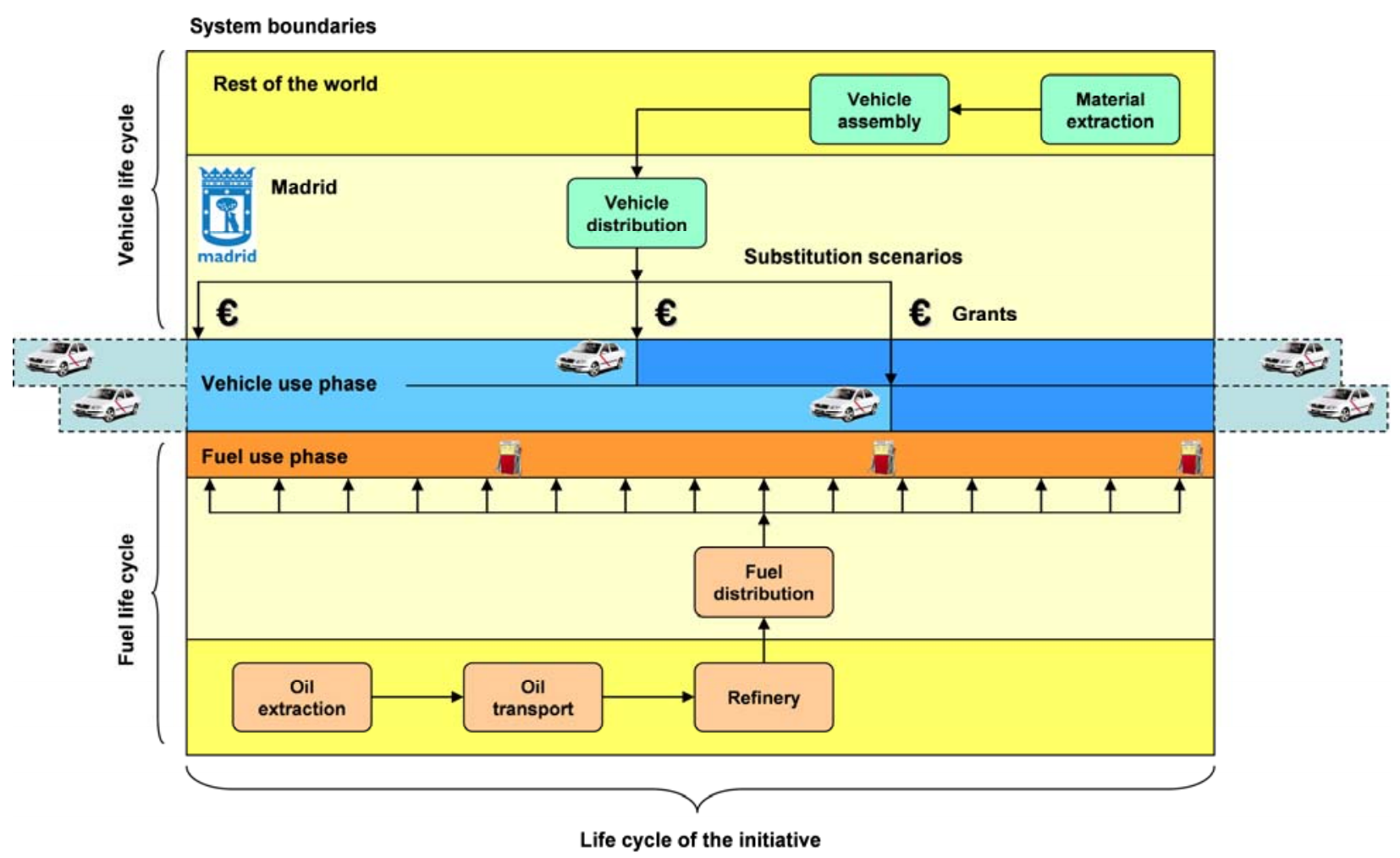

Figure 1. Schematic representation of a taxi fleet life cycle.

The geographic domain of this analysis for the use-phase was limited to the territorial unit of the Municipality of Madrid and surrounding cities (Figure 2). When the analysis focuses of the complete life cycle, references to Spain and other relevant countries are made. The analysis timeframe will be $2015+$, focusing on the year in which the local air quality plan will conclude.

\subsection{Function and functional unit}

The function of the analyzed system is the transportation of passengers by taxis throughout the city of Madrid for an average mileage. According to the traffic model of the Municipality of Madrid, the annual average mileage of a taxi in the city is 63,200 
$\mathrm{km} / \mathrm{yr}$ with a total life of 6.75 years. The total life of a taxi in Madrid was estimated using the respective life curves provided by the EmiTRANS Project (Lumbreras et at., 2013) and the GlobalTRANS database (Pérez et al., 2012). The functional unit for analysis was one vehicle per traveled kilometer (1 veh·km).

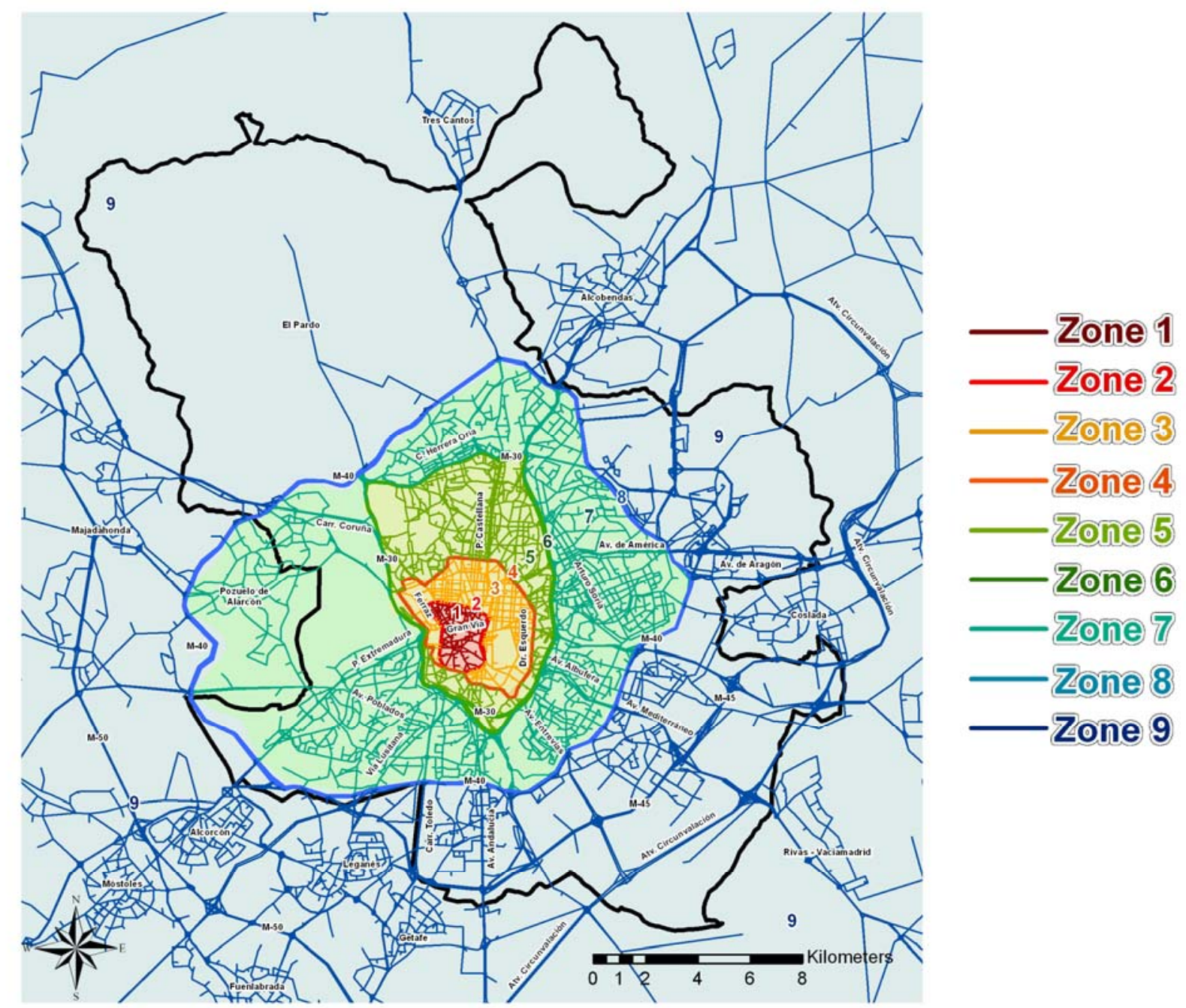

Figure 2. Road network of the traffic model (studied domain). Black line: boundaries of the Municipality of Madrid. 


\subsection{Comparison scenarios}

In order to evaluate the impact of the municipal decision under different perspectives, four scenarios were built and analyzed (i) a "business-as-usual” scenario (BAU), (ii) the expected scenario at the conclusion of the Madrid AQP in 2015, (iii) a conservative “all-diesel” vehicles scenario (ADI), and (iv) an optimistic "all-ecologic" vehicles scenario (AEC). These scenarios show the composition of the taxi fleet (15700 vehicles) according to a series of hypotheses based on technology costs, raw materials and energy prices, taxes, expected sales and types of customers according to Jazcilevich et al., (2011) and Propfe et al., (2013). For the construction of these scenarios, a modelspecific taxi fleet with 15,708 vehicles was provided by the Municipality of Madrid for 2011. The most representative models and years for every considered fuel type are shown in Table 1 and Figure 3. No new incorporations to the fleet or changes due to breakdowns or accidents were considered whatsoever.

Table 1. Model composition and characteristics of the taxi fleet in Madrid.

\begin{tabular}{|c|c|c|c|c|}
\hline Model & Fuel & Technology & Year & Assembly Location \\
\hline SEAT Altea 1.6 TDI & $\begin{array}{l}\text { Diesel, } \\
\text { LPG }\end{array}$ & Euro 4, 5 & $2011+$ & \multirow{2}{*}{ Martorell, Spain } \\
\hline SEAT Toledo 1.9 TDI & $\begin{array}{l}\text { Diesel, } \\
\text { LPG }\end{array}$ & Euro 4, 5 & $2011+$ & \\
\hline Škoda Octavia 1.6 TDI & $\begin{array}{l}\text { Diesel, } \\
\text { LPG }\end{array}$ & Euro 4, 5 & $2011+$ & \multirow{2}{*}{$\begin{array}{c}\text { Mladá Boleslav, Czech } \\
\text { Republic }\end{array}$} \\
\hline Škoda Superb 2.0 TDI & $\begin{array}{l}\text { Diesel, } \\
\text { LPG }\end{array}$ & Euro 4, 5 & $2011+$ & \\
\hline $\begin{array}{c}\text { Volkswagen Passat } \\
\text { 2.0 TDI }\end{array}$ & Diesel & Euro 4, 5 & $2011+$ & Emden, Germany \\
\hline $\begin{array}{c}\text { Volkswagen Jetta } \\
2.0 \text { TDI }\end{array}$ & Diesel & Euro 4, 5 & $2011+$ & Puebla, Mexico \\
\hline Toyota Prius 1.8 & $\begin{array}{l}\text { Gasoline- } \\
\text { Hybrid }\end{array}$ & Euro 4 & $2011+$ & Tsutsumi, Japan \\
\hline $\begin{array}{c}\text { Opel Zafira 1.6 CNG } \\
\text { EcoFlex }\end{array}$ & CNG & Euro 4,5 & $2011+$ & Bochum, Germany \\
\hline
\end{tabular}

For this study case, BAU considers that the taxi composition in 2015 is a consequence of the normal evolution of the vehicle fleet according to a usual market-flow. This 
scenario has a limited share of the so-called ecologic alternatives, being diesel vehicles highly predominant (Fig. 3). AQP corresponds to the composition of the taxi fleet forecasted by the Municipality of Madrid in its AQP and, in a strict sense it should reflect realistically the penetration-degree of the initiative under normal circumstances (AM, 2012). Compared to BAU, this scenario considers an important share of hybrid vehicles and a slightly larger penetration of LPG and CNG technologies. ADI considers that every taxi is diesel-fueled (Fig. 3), trying to reproduce a situation of failure of the environmental initiative and can be considered as a "worst-case scenario". Conversely, AEC reproduces a situation of success of the initiative in which all the taxis belong to the ecologic alternatives supported by the environmental initiative, reflecting the best feasible scenario (Fig. 3).

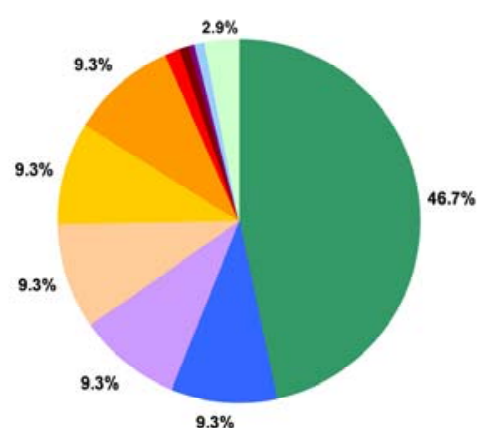

Business as usual (BAU)

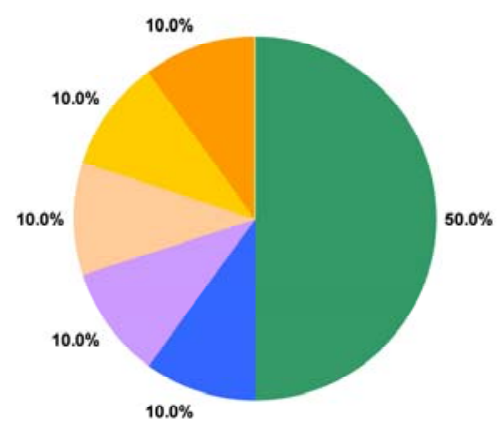

All - Diesel (ADI)

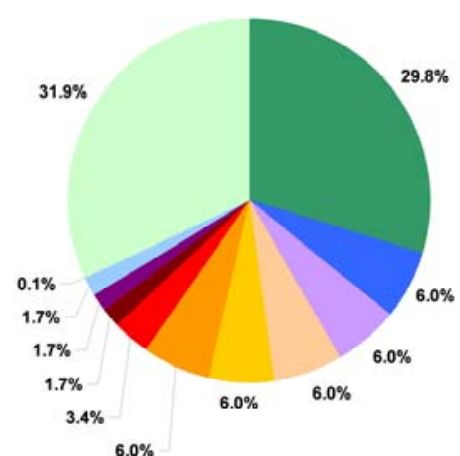

Air quality plan (AQP)

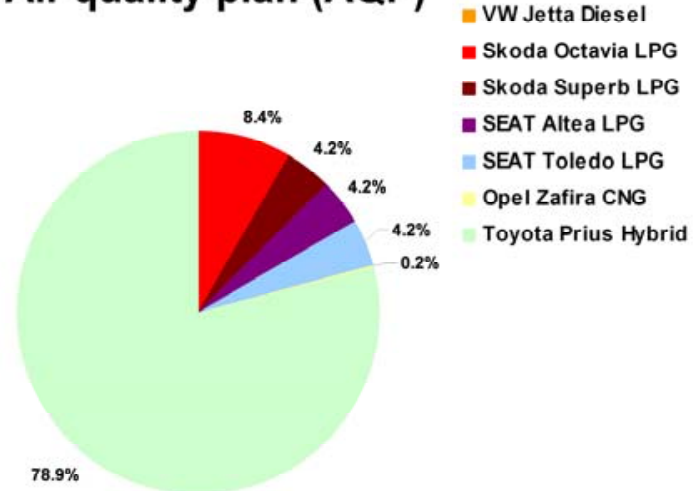

All - Ecologic (AEC)

Figure 3. Vehicle composition by model and fuel in the four 2015 scenarios. Total number of taxis: 15700 vehicles. 


\subsection{Fuel life cycle characterization}

Table 2. Countries of origin, transportation modes and share of the total crude imported to Spain in 2012.

\begin{tabular}{|c|c|c|c|}
\hline Country of Origin & Varieties & $\begin{array}{l}\text { \% Total } \\
\text { Crude }\end{array}$ & Transportation modes \\
\hline Algeria & Condensate, Sahara & $0.81 \%$ & $\begin{array}{c}\text { In Amenas-Bejaia Pipeline } \\
\text { Hassi R'mel-Arzew Pipeline } \\
\text { Oil Tanker }\end{array}$ \\
\hline Angola & Dalia, Girassol & $2.34 \%$ & Oil Tanker \\
\hline Brazil & Albacora & $1.74 \%$ & Oil Tanker \\
\hline Colombia & Castilla & $0.21 \%$ & $\begin{array}{c}\text { Caño Limón-Coveñas Pipeline } \\
\text { Oil Tanker }\end{array}$ \\
\hline Congo-Brazzaville & Djeno & $2.07 \%$ & Oil Tanker \\
\hline Iraq & Kirkuk & $2.73 \%$ & $\begin{array}{c}\text { Kirkuk-Ceyhan Pipeline } \\
\text { Oil Tanker }\end{array}$ \\
\hline $\begin{array}{l}\text { Islamic Republic of } \\
\text { Iran }\end{array}$ & $\begin{array}{c}\text { Foroozan, Iranian } \\
\text { Heavy, Iranian Light, } \\
\text { Soroosh } \\
\end{array}$ & $13.99 \%$ & $\begin{array}{c}\text { Yanbu Pipeline } \\
\text { SUMED Pipeline } \\
\text { Oil Tanker } \\
\end{array}$ \\
\hline Libya & $\begin{array}{c}\text { Bouri, El Sharara, Es } \\
\text { Sider, Sirtica, Mellitah }\end{array}$ & $17.20 \%$ & $\begin{array}{c}\text { Amal-Ra’s Lanuf/Sirtica Pipeline } \\
\text { Waha Pipeline } \\
\text { Oil Tanker }\end{array}$ \\
\hline Mexico & Istmo, Maya & $29.51 \%$ & $\begin{array}{c}\text { Cantarell-Cayo Arcas Pipeline } \\
\text { Dos Bocas Pipeline } \\
\text { Oil Tanker } \\
\end{array}$ \\
\hline Norway & Oseberg & $1.70 \%$ & $\begin{array}{c}\text { Oseberg-Sture Pipeline } \\
\text { Oil Tanker }\end{array}$ \\
\hline Russian Federation & $\begin{array}{l}\text { Siberia Light, Ural } \\
\text { Light, Ural } \\
\text { Novorossyisk, Ural } \\
\text { Primorsk } \\
\end{array}$ & $7.84 \%$ & $\begin{array}{c}\text { Omsk-Novorossyisk Pipeline } \\
\text { Omsk-Primorsk Pipeline } \\
\text { Irkutsk-Tuapse Pipeline } \\
\text { Oil Tankers } \\
\end{array}$ \\
\hline Saudi Arabia & Arabia Light & $16.66 \%$ & $\begin{array}{l}\text { Yanbu Pipeline } \\
\text { SUMED Pipeline } \\
\text { Oil Tanker }\end{array}$ \\
\hline Syrian Arab Republic & Souedie & $1.43 \%$ & $\begin{array}{c}\text { Karaichok-Tartous Pipeline } \\
\text { Oil Tanker } \\
\end{array}$ \\
\hline Tunisia & Ashtart & $1.74 \%$ & Oil Tanker \\
\hline
\end{tabular}

\subsubsection{Crude exploration and production}

The crude exploration and production phase was characterized attending to the oil varieties that are imported to Spain. Table 2 contains information on the share of the different oil-exporting countries to the total crude purchased in 2012 (CORES, 2011). These origins and shares were the same for every fuel consumed in Spanish territory and kept constant during the entire period of analysis. Information regarding airborne ${ }^{1}$ emissions of the exploration, drilling and extraction operations was taken from the

\footnotetext{
${ }^{1}$ The term “emissions” hereinafter refers only to those of airborne nature.
} 
International Association of Oil and Gas Producers for on-shore and off-shore operations in the respective countries (OGP, 2010). Energy consumptions associated to this stage are listed in Table 3.

\subsubsection{Transportation to refinery}

The transportation of the different crude varieties from their respective sources to Spanish territory was carried out either by oil tankers or pipelines. Crude oil was received at the ports of Rota or Cartagena depending on the transport routes and sent to the refinery through two pipelines (Repsol, 2012). In every case, routes were calculated using the exact geographic locations of wells, pipelines and marine terminals (Libyan NOC, 2010; Lukoil, 2012; Pemex, 2013; Saudi-Aramco, 2012; Sonatrach, 2013; Statoil, 2012; Total-E\&P Congo, 2012; Total-E\&P Sonangol, 2005). Information on the 2012 vessel fleet, such as name, flag of registry, average speed, gross tonnage, and dead weight was available as well as the routes and crude varieties carried by each of the tankers (CORES, 2011; Puertos del Estado, 2011). Energy consumptions associated to pipelines have been estimated as in Menegaki (2011). Emissions related to maritime and pipeline transportations as well as handling and storage in ports were calculated according to the EMEP/EEA 2009 methodology (EEA, 2009). References on the transportation modes of the imported crude varieties are shown in Table 2 and 3. For the specific case of natural gas, transport is made exclusively by the Magreb-Europa pipeline and sent directly to a conditioning/storage facility near Madrid (Sonatrach, 2013). 
Table 3. Energy consumptions associated to the different stages of the fuel life cycle (TtW phase).

\begin{tabular}{|c|c|c|}
\hline Fuel life cycle stage & Process & $\begin{array}{c}\text { Energy } \\
\text { Consumption } \\
\left(\mathbf{M J} / \mathbf{t}_{\text {crude }}{ }^{\mathrm{a}}\right) \\
\end{array}$ \\
\hline \multirow{14}{*}{ Crude Exploration and Production } & Operations in Algeria & 682 \\
\hline & Operations in Angola & 7 \\
\hline & Operations in Brazil & 12 \\
\hline & Operations in Colombia & 2 \\
\hline & Operations in Congo, Brazzaville & 10 \\
\hline & Operations in Iraq & 8 \\
\hline & Operations in Iran, Islamic Republic of & 11 \\
\hline & Operations in Libya & 59 \\
\hline & Operations in Mexico & 322 \\
\hline & Operations in Norway & 8 \\
\hline & Operations in Russian Federation & 19 \\
\hline & Operations in Saudi Arabia & 66 \\
\hline & Operations in Syria, Arab Republic of & 4 \\
\hline & Operations in Tunisia & 8 \\
\hline & Total & 545 \\
\hline Transportation to Refinery & & \\
\hline \multirow{13}{*}{ Pipeline (off-shore) } & Transport in Algeria & 0.02 \\
\hline & Transport in Colombia & 0.38 \\
\hline & Transport in Egypt & $1.09 \times 10^{-5}$ \\
\hline & Transport in Iraq & 2.06 \\
\hline & Transport in Libya & 9.81 \\
\hline & Transport in Mexico & 4.77 \\
\hline & Transport in Norway & 0.35 \\
\hline & Transport in Russian Federation & 11.92 \\
\hline & Transport in Saudi Arabia & 0.38 \\
\hline & Transport in Syria, Arab Republic of & 1.71 \\
\hline & Transport in Turkey & 3.19 \\
\hline & Transport in United Kingdom & 0.17 \\
\hline & Total & 72.10 \\
\hline \multirow{3}{*}{ Pipeline (on-shore) } & Transport in Spain (from Rota) & 48.60 \\
\hline & Transport in Spain (from Cartagena) & 29.10 \\
\hline & Total & 77.70 \\
\hline \multirow{12}{*}{ Vessels (oil tankers) } & Oil tankers - Flag of Bahamas & $1.20 \times 10^{4}$ \\
\hline & Oil tankers - Flag of Cyprus & $9.92 \times 10^{2}$ \\
\hline & Oil tankers - Flag of Greece & $2.59 \times 10^{4}$ \\
\hline & Oil tankers - Flag of Liberia & $5.30 \times 10^{3}$ \\
\hline & Oil tankers - Flag of Malta & $5.73 \times 10^{3}$ \\
\hline & Oil tankers - Flag of Marshall Islands & $3.73 \times 10^{3}$ \\
\hline & Oil tankers - Flag of Norway & $5.92 \times 10^{3}$ \\
\hline & Oil tankers - Flag of Panama & $4.99 \times 10^{2}$ \\
\hline & Oil tankers - Flag of Singapore & $6.52 \times 10^{3}$ \\
\hline & Oil tankers - Flag of United Kingdom & $2.73 \times 10^{3}$ \\
\hline & Oil tankers - Other Flags ${ }^{b}$ & $8.73 \times 10^{5}$ \\
\hline & Total & $9.42 \times 10^{5}$ \\
\hline & Total & $9.42 \times 10^{5}$ \\
\hline \multirow{5}{*}{ Conversion and Refining } & Consumption of Fueloil & $1.96 \times 10^{3}$ \\
\hline & Consumption of Gasoil & $1.07 \times 10^{-1}$ \\
\hline & Consumption of Natural Gas & $4.99 \times 10^{2}$ \\
\hline & Consumption of Refinery Gas & $2.53 \times 10^{3}$ \\
\hline & Consumption of Other Fuels & $1.45 \times 10^{1}$ \\
\hline & Total & $5.01 \times 10^{3}$ \\
\hline \multicolumn{3}{|l|}{ Storage and Transportation to Filling Stations } \\
\hline \multirow{3}{*}{ Transport to Storage Hub (Pipeline) } & Transport of Gasoline to Storage Hub & $4.01 \times 10^{3}$ \\
\hline & Transport of Diesel to Storage Hub & $7.02 \times 10^{3}$ \\
\hline & Total & $1.10 \times 10^{4}$ \\
\hline
\end{tabular}




\begin{tabular}{l|l|c|}
\hline Transport to Filling Stations (Pipeline) & Transport of LPG to Filling Stations & $4.06 \times 10^{3}$ \\
\hline \multirow{2}{*}{ Transport to Filling Stations (Truck) } & Transport of Gasoline to Filling Stations & 19.5 \\
\cline { 2 - 3 } & Transport of Diesel to Filling Stations & 19.1 \\
\cline { 2 - 3 } & \multicolumn{1}{|c|}{ Total } & 38.5 \\
\hline Total of the Well-to-Tank (WtT) stage & $\mathbf{1 . 9 0 \times 1 0 ^ { \mathbf { 6 } }}$ \\
\hline
\end{tabular}

\subsubsection{Conversion and refining}

The conversion and refining of oil was assumed to be carried out by a representative deep-conversion refinery operating in Spain. It was assumed that this refinery is located in south-central Spain, at $300 \mathrm{~km}$ from Cartagena and $500 \mathrm{~km}$ from Rota. The characteristics of the process were defined according to the latest BREF document on Refining of Mineral Oil and Gas (EC, 2003) while the associated emissions were calculated as specified in the EMEP/CORINAIR methodology (EEA, 2009) and the 2011 Spain’s National Emission Inventory (MAGRAMA, 2013). The share of the different fuels produced by this refinery is presented in Table 4, while the related energy consumptions are listed in Table 3.

Table 4. Approximate annual outputs produced by the representative refinery in Spain.

\begin{tabular}{|c|c|c|}
\hline Product & Output (t/yr) & $\begin{array}{c}\text { Percentage (weight) of } \\
\text { production (\%) }\end{array}$ \\
\hline LPG & 85,000 & $1.5 \%$ \\
\hline Gasoline & $1,100,000$ & $16.8 \%$ \\
\hline Diesel & $3,200,000$ & $57.4 \%$ \\
\hline
\end{tabular}

\subsubsection{Storage and transportation to filling stations}

The transportation of fuels from the refinery to an intermediate storage point was considered to be carried out by a 200-km pipeline. Once stored, fuels were distributed using a typical 30-t Volvo tank-truck equipped with a diesel Euro IV engine. The corresponding energy consumptions are shown in Table 3. We assumed that these 
trucks are fueled with diesel from the storage point and that distribution is carried out in Madrid, located $30 \mathrm{~km}$ away. The emissions related to pipeline transportation as well as fuel storage and filling were estimated according to the EMEP/EEA methodology (EEA, 2009) while the emissions associated to the trucks were calculated with data provided by Volvo (VTC, 2003).

\subsection{Material life cycle characterization}

\subsubsection{Extraction and production of raw materials}

The extraction and production of raw materials was modeled attending to the specific mass compositions of the selected vehicles (Table 1), which were obtained from the GlobalTRANS database (Pérez et al., 2012) and Leduc et al., (2010). Due to the lack of information on this stage, emissions inventories were elaborated using data from a complete and updated version of the Eco-Invent database (Frischknecht et al., 2004).

\subsubsection{Vehicle assembly and distribution}

Due to the lack of specific information regarding the assembly processes of the different vehicles, data from the GlobalTRANS project (Pérez et al., 2012) were incorporated for assembly facilities located outside Spain. For factories located in Spain, specific data from the Spain's National Emission Inventory were used (MAGRAMA, 2013). The transportation of vehicles from their assembly facilities to Madrid was carried out by car-carrier trucks for land routes and vessels for sea routes. A 28-t Volvo carrier truck with a Euro IV diesel engine and space for 5 cars was chosen for land transportation while sea transportation was made using a ship with a gross-tonnage similar to a car- 
carrier vessel $(G T=44000)$. Distances were calculated using the exact geographic locations of the assembly plants, highway distances and typical sea transit routes. Vehicles manufactured in Mexico were sent to Vigo from Tampico, while those manufactured in Japan were sent to the Barcelona from Yokohama.

\subsection{Electricity}

The electricity mixes of each of the countries involved in any stage of either the fuel or the material life cycles were characterized using the 2012 national electricity consumptions from the International Energy Agency (IEA, 2011) and power-generation emissions estimated for the same year by the Emissions Database for Global Atmospheric Research (EDGAR) (Janssens-Maenhout et al., 2012). Additional considerations regarding electricity consumption patterns were made as published in Koroneos and Nanaki, (2007). The Spanish electricity mix was estimated with data coming from the 2011 Spain’s National Emission Inventory (MAGRAMA, 2013) and the National Energy Outlook (MINETUR, 2012).

\subsection{Use-phase characterization}

The before mentioned fuel and material life cycles converge at the vehicle use-phase (TtW), which was modeled paying special attention to the specific conditions of the city as well as the particularities of the vehicle fleet. It is well known that exhaust emissions are a function of the attributes (i.e. fuel type, engine, technology) of the different vehicle types and of the driving conditions (Ntziachristos and Samaras, 2001). 
To this respect, the calculation of fuel-consumptions and road-traffic emissions factors was carried out with COPERT 4 (Ntziachristos et al., 2009), which is an average speed model considering three different driving patterns (rural, urban and motorway). The decision of using COPERT was made in order to be consistent with the EMEP/CORINAIR methodology, already applied in the quantification of emissions of other life cycle stages (sections 3.4.2, 3.4.3). Its adequateness to the particular conditions of Madrid has already been contrasted against observations in other studies (Vedrenne et al., 2011; Borge et al., 2012; Borge et al., 2014). This model was fed with information from the traffic model of the Municipality of Madrid which is a macroscopic simulation model for dynamic equilibrium traffic assignment supported by a Geographic Information System (GIS) where the road network of the metropolitan area of Madrid is represented by 14,938 roads and divided into 9 different management zones (Figure 1) (Borge et al., 2012). These zones have been separated according to vehicle flows, mean speeds and management importance in the city; three of them correspond to specific ways/circuits while the remaining six are geographic areas that enclose the rest of the road network (Table 5). No mobility or road infrastructure changes were considered whatsoever.

\subsection{Impact characterization and allocation}

The characterization of impacts in this study was carried out at the midpoint level according to the International Reference Life Cycle Data System (ILCD) methodology (2011 Midpoint V1.01) and only for those impact categories closely related to the air quality situation in Madrid: acidification (AC), climate change (CC), particulate matter (PM), photochemical ozone formation (PO) and terrestrial eutrophication (TE) (EC, 2011). Impact allocation procedures were carried out only for the WtT stages, namely 
crude extraction, fuel transportation and fuel refining. The allocation criterion was the percentage (in weight) of the produced fuels by the refinery in 2012 (Table 4).

Table 5. Characteristics of the traffic management zones in the city of Madrid.

\begin{tabular}{|c|c|c|c|c|c|}
\hline Zone & $\begin{array}{l}\text { Driving } \\
\text { Pattern }^{\mathrm{C}}\end{array}$ & $\begin{array}{l}\text { Mean } \\
\text { Speed } \\
(\mathbf{k m} / \mathbf{h})\end{array}$ & $\begin{array}{c}\text { Annual } \\
\text { mileage } \\
(\mathbf{k m})\end{array}$ & Area/Length ${ }^{\mathrm{d}}$ & Representative roads/streets \\
\hline 1 & $\mathrm{U}$ & 17.8 & 1255 & $4.3 \mathrm{~km}^{2}$ & $\begin{array}{l}\text { Gran Vía, Alcalá, San Bernardo, Atocha, } \\
\text { Princesa }\end{array}$ \\
\hline 2 & $\mathrm{U}$ & 20.9 & 997 & $9.7 \mathrm{~km}$ & $\begin{array}{l}\text { Bailén, Rda. Toledo, Rda. Valencia, P. Prado, } \\
\text { P. Recoletos, Génova, Sagasta, Alberto } \\
\text { Aguilera, M. de Urquijo, Pintor Rosales, } \\
\text { Ferraz }\end{array}$ \\
\hline 3 & $\mathrm{U}$ & 21.0 & 6317 & $13.4 \mathrm{~km}^{2}$ & $\begin{array}{l}\text { Alcalá, Serrano, Velásquez, Goya, P. } \\
\text { Castellana, Cd. de Barcelona, Sta. Engracia, } \\
\text { Guzmán el Bueno, O’Donnell, Ppe. de } \\
\text { Vergara }\end{array}$ \\
\hline 4 & $\mathrm{U}$ & 23.3 & 1089 & $26.3 \mathrm{~km}$ & $\begin{array}{l}\text { Av. Valladolid, P. Florida, Rda. Segovia, } \\
\text { Rda. Toledo, Embajadores, Ferrocarril, Mdz. } \\
\text { Álvaro, Dr. Esquerdo, Fco. Silvela, R.F. } \\
\text { Villaverde, Reina Victoria, Sn. Fco. de Sales, } \\
\text { Av. Filipinas }\end{array}$ \\
\hline 5 & $\mathrm{U}$ & 27.1 & 6221 & $33.7 \mathrm{~km}^{2}$ & $\begin{array}{l}\text { P. Castellana, Bravo Murillo, Av. América, } \\
\text { Ppe. de Vergara, Pio XII, Ramón y Cajal, M. } \\
\text { de Viana, Sinesio Delgado, P. Delicias }\end{array}$ \\
\hline 6 & $\mathrm{H}$ & 68.8 & 3429 & $31.0 \mathrm{~km}$ & M-30 \\
\hline 7 & $\mathrm{U}$ & 51.9 & 10602 & $157.5 \mathrm{~km}^{2}$ & $\begin{array}{l}\text { P. Extremadura, Av. de los Poblados, Vía } \\
\text { Lusitana, Av. Albufera, Av. Entrevías, Arturo } \\
\text { Soria, Hnos. García Noblejas, Alcalá, Herrera } \\
\text { Oria }\end{array}$ \\
\hline 8 & $\mathrm{H}$ & 90.0 & 5777 & $59.1 \mathrm{~km}$ & $\mathrm{M}-40$ \\
\hline 9 & $\mathrm{H}$ & 88.1 & 8308 & $1551.1 \mathrm{~km}^{2}$ & $\begin{array}{l}\text { M-45, M-50, Autov. Circunvalación, Av. } \\
\text { Andalucía, Av. Aragón, Carr. Toledo, Av. } \\
\text { Ensanche de Vallecas }\end{array}$ \\
\hline
\end{tabular}

${ }^{c}$ U-urban driving pattern, H-highway driving pattern. ${ }^{\mathrm{d}}$ Zones $1,3,5,7$ and 9 correspond to areas. Zones 2,4,6 and 8 are lines.

\subsection{Analysis tools}

The analysis was carried out according to the International Standards Organization (ISO) 14040 and 14044 regarding life cycle assessment standards, data reductions and allocation procedures. To guarantee consistency and a good practice, the SimaPro 7.3 software for LCA was extensively used. SimaPro is a process-based inventory model 
marketed as a user-friendly software interface that allows data assembled by the user in order to conduct environmental impact and life cycle analyses (Garg et al., 2013).

\section{Results and discussion}

\subsection{Life cycle analysis}

The analysis of the complete life cycle involved considering the interactions and impacts of 2,465 processes for each analyzed scenario. The evaluated impacts (Table 6) have been analyzed by grouping them into 6 categories, according to their function in the complete life cycle: (i) vehicle manufacturing, (ii) vehicle transportation, (iii) crude extraction, (iv) fuel transportation, (v) fuel refining and (vi) vehicle use-phase. More specifically, the fuel transportation category includes the transportation of crude oil from the different sources to Spain, as well as the distribution operations of refined fuels. Likewise, the vehicle manufacturing category includes the impacts associated with the extraction and production of raw materials (section 3.5.1). The absolute impacts generated by the different scenarios for each of the above mentioned categories are seen in Figure 4, while their respective share on the total impacts is shown in Figure 5.

Table 6. Life cycle analysis results for the selected categories under the four tested scenarios according to the ILCD midpoint level methodology.

\begin{tabular}{|c|c|c|c|c|}
\hline Impact & BAU & AQP & ADI & AEC \\
\hline Acidification $\left(\mathrm{kmol}_{\mathrm{H}+\mathrm{eq}}\right)$ & 14020 & 10597 & 14768 & 4445 \\
\hline Climate Change $\left(\mathrm{Gg}_{\mathrm{CO} 2 \mathrm{eq}}\right)$ & 1365 & 1189 & 1390 & 893 \\
\hline Particulate Matter $\left(\mathrm{Mg}_{\mathrm{PM} 2.5 \mathrm{eq}}\right)$ & 978 & 752 & 1029 & 345 \\
\hline Photochemical Ozone Formation $\left(\mathrm{Mg}_{\text {NMVOCeq }}\right)$ & 13336 & 10035 & 14068 & 4086 \\
\hline Terrestrial Eutrophication $\left(\mathrm{kmol}_{\text {Neq }}\right)$ & 49396 & 36020 & 52197 & 12164 \\
\hline
\end{tabular}



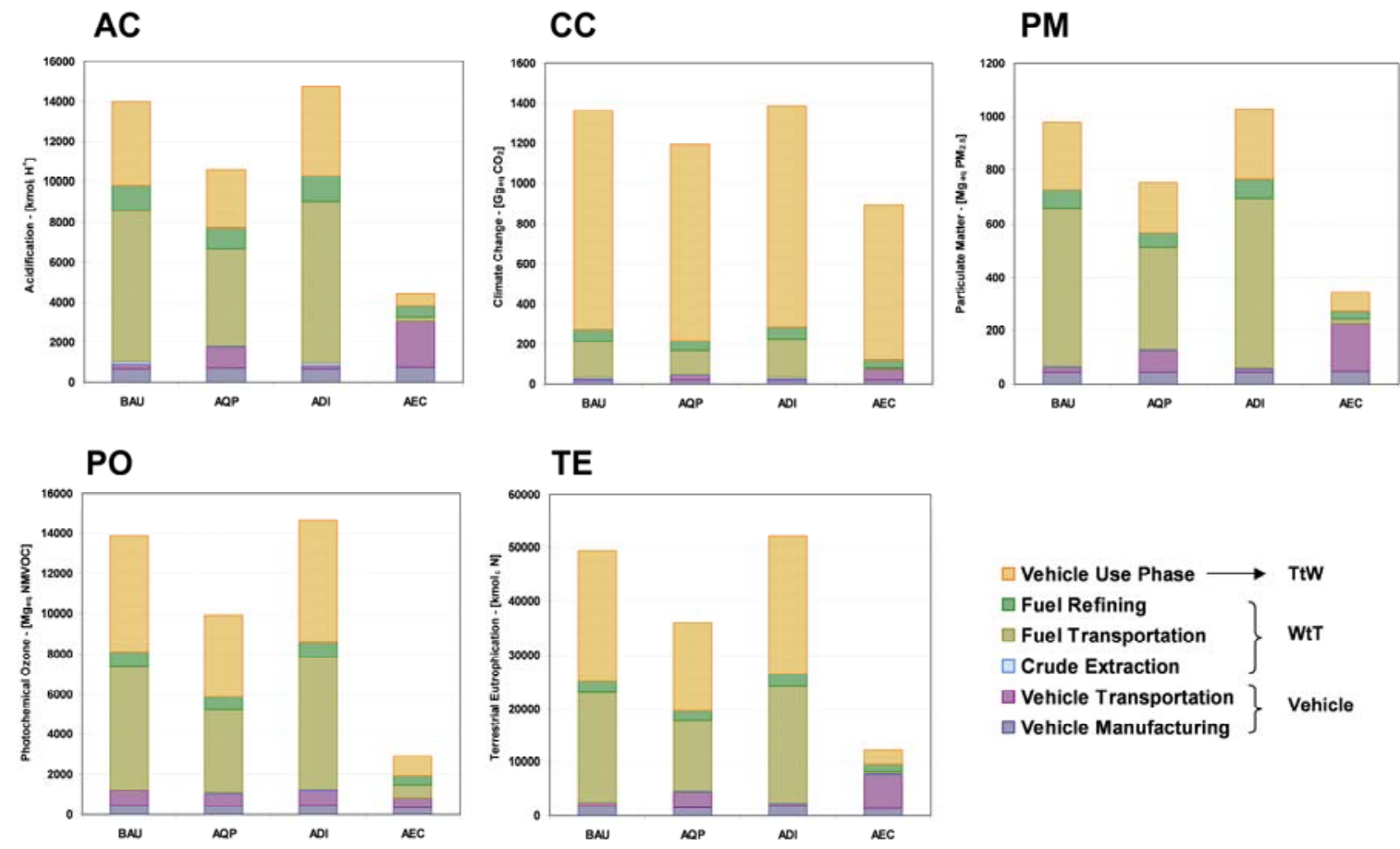

Figure 4. Comparison of the total impacts produced by the studied scenarios for the complete life cycle. AC: acidification. CC: climate change. PM: particulate matter. PO: photochemical ozone formation. TE: terrestrial eutrophication. WtT: Well to Tank phase. TtW: Tank to Wheels phase.

The comparison between the four scenarios revealed that in absolute terms, ADI has the largest impacts associated, followed by BAU, AQP and AEC. Since ADI and AEC are respectively the worst and best tested scenarios, these can be used as reference for planning a feasible fleet composition. It can also be interpreted from Fig. 4 that according to the impact category, the incorporation of ecologic vehicles is translated to diverse reduction percentages from the reference scenario, which means that a given initiative has different effects on the problem to tackle. For example, the adoption of an AEC scenario implies reducing a 34.5\% of CC-related impacts if compared to BAU and a $35.7 \%$ if compared to ADI, while for PO impacts the reduction of AEC against BAU and ADI is $69.3 \%$ and $70.9 \%$ respectively. This fact is a direct consequence of the sensitivity of the described processes to a given impact, whose identification is crucial in order to identify possible courses of action under a policy-making perspective. 


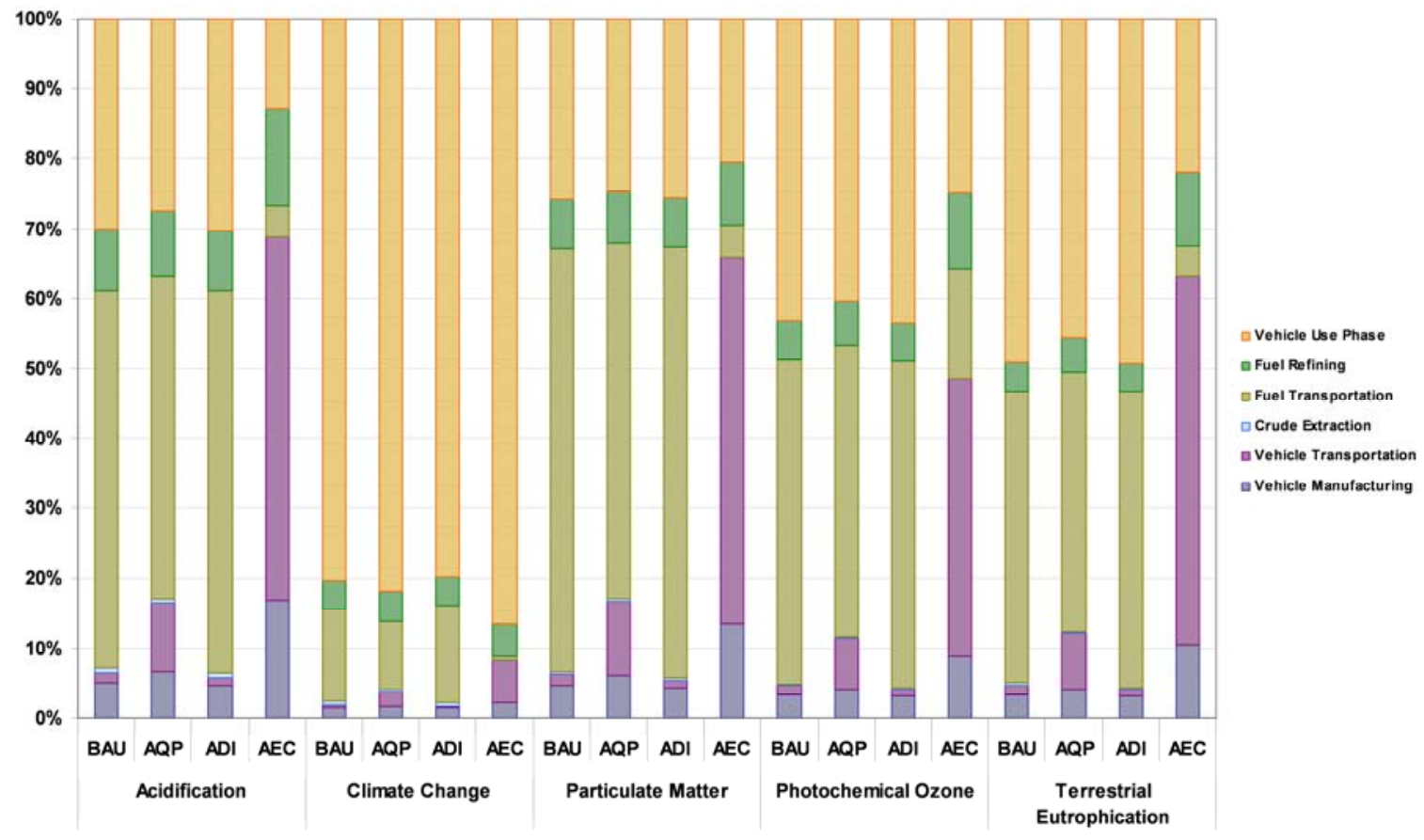

Figure 5. Comparison of the contribution of the life cycle stages to the impacts produced by the studied scenarios.

This discussion can be extended by analyzing the shares of the selected categories for each of the impacts considered. From Fig. 5, one can see that the fuel transportation, vehicle transportation and vehicle use-phase categories have the largest shares, along with a small participation of fuel refining and an almost negligible contribution from crude extraction. The vehicle use-phase ( $\mathrm{TtW})$ is the dominant part of the life cycle for every impact, and for AC, PM and TE the vehicle and fuel transportation phases also exert a considerable influence (Leduc et al., 2010). The high share of the use-phase for CC-related impacts is basically the consequence of fuel consumptions by taxis, which emit $\mathrm{CO}_{2}$ as major exhaust-compound. The contribution of the use-phase to the rest of the impacts is more modest regarding $\mathrm{PM}$ and $\mathrm{AC}$, due to the fact that most of the models in the fleet have PM-emission control technologies such as gas recirculation and particle filters (Euro 4,5), while the low-sulfur composition of fuels limits the amount of 
related acidifiers (Tzamkiozis et al., 2010). On the contrary, it is not possible to avoid the emission of typical road-traffic compounds such as $\mathrm{NO}_{\mathrm{x}}$, which are the responsible for the important shares of the use-phase in PO and TE-related impacts.

In the case of $\mathrm{AC}, \mathrm{PM}$ and $\mathrm{TE}$, the large share of the vehicle and fuel transportation phases is mainly related with ship exhaust emissions derived from crude-oil transport operations from distant countries as well as the manufacturing of vehicles abroad (i.e. Japan, in the case of hybrid vehicles). The large travel distances that exist between these countries and Spain, combined with the fact that oil tankers and cargo vessels are usually propelled with heavy fuels makes these categories a significant source of air pollution, especially regarding PM and sulfur acidifiers (Hulskotte and Denier van der Gon, 2010). This is especially true when more than $65 \%$ of the total oil imported by Spain comes from faraway countries such as Angola, Brazil, Colombia, Iran, Mexico or Saudi Arabia (Table 2). Regarding the transportation of vehicles, the largest contributions are present in AEC as a consequence of the big share of vehicles that are transported by sea from Japan and the observed lower consumption of fuels in the usephase. For the specific case of PO, high impacts are caused by NMVOC fugitive emissions, which are usually present in fuel handling and storage operations, specifically at pipelines and marine terminals (Klimont et al., 2002).

The shares of the vehicle manufacturing and fuel refining categories are intimately related to the scenarios' fleet compositions, with the highest percentages present in AEC. These differences can be attributed to the fact that this scenario has a large fleet of hybrid vehicles (Fig. 3) whose manufacturing process is reputed not being as ecofriendly as that of conventional vehicles, which is basically a consequence of the battery assembly process (Pollet et al., 2012). The variations that are observed in the 
contribution of the fuel refining process for every impact in the four scenarios are a consequence of the applied impact allocation hypotheses. According to section 3.7, the allocation criterion was based on the weight percentage of the different fuels produced by the refinery (Table 4). Since the refinery's major product is diesel, the impacts associated to the refining stage were observed to increase for diesel-intensive scenarios such as BAU or ADI (Fig. 4).

The analysis of the complete life cycle as presented in this section is useful for assessing the total environmental impact of each of the possible outcomes as a whole. However, this analysis has not been focused on the scale on which these impacts are produced, which is very relevant since decision-making is usually limited by specific territorial boundaries. To this respect, placing this analysis at the local context is useful for guiding stakeholders on planning activities. The following discussion will be focused only on the use-phase due to the fact that it is the only part of the life cycle that takes place exclusively in Madrid.

\subsection{Use-phase analysis}

The detailed characterization of the use-phase (section 3.7), especially regarding the conditions in which it is carried out (speeds, traffic flows, technologies, etc.) responds to the need of having estimates that are as accurate and as realistic as possible in order to be used for policy-support. The distinction of road-traffic emissions in nine management zones is a consequence of the different emission rates that vehicles exhibit as a function of circulation conditions, which are highly variable at urban environments (Fontaras and Samaras, 2010). Moreover, this division is useful to identify zones that are more likely of benefiting from the adoption of the environmental initiative. 
Table 7. Use-phase analysis results for the selected categories for the two policy-relevant scenarios according to the ILCD midpoint level methodology.

\begin{tabular}{|l|c|c|c|c|c|c|c|c|c|c|}
\hline \multirow{2}{*}{ Zone } & \multicolumn{2}{|c|}{ Acidification } & \multicolumn{2}{c|}{$\begin{array}{c}\text { Climate } \\
\text { Change }\end{array}$} & \multicolumn{2}{c|}{$\begin{array}{c}\text { Particulate } \\
\text { Matter }\end{array}$} & \multicolumn{2}{c|}{$\begin{array}{c}\text { Photochemical } \\
\text { Ozone }\end{array}$} & \multicolumn{2}{c|}{$\begin{array}{c}\text { Terrestrial } \\
\text { Eutrophication }\end{array}$} \\
\cline { 2 - 12 } & $\mathbf{B A U}$ & $\mathbf{A Q P}$ & BAU & AQP & BAU & AQP & BAU & AQP & BAU & AQP \\
\hline Zone 1 & 14.00 & 9.03 & 3443 & 2878 & 0.78 & 0.56 & 19.65 & 15.48 & 80.40 & 51.79 \\
\hline Zone 2 & 13.20 & 8.52 & 3224 & 2729 & 0.76 & 0.55 & 18.57 & 15.50 & 75.81 & 48.86 \\
\hline Zone 3 & 13.20 & 8.52 & 3225 & 2730 & 0.76 & 0.55 & 18.29 & 12.42 & 75.84 & 48.88 \\
\hline Zone 4 & 12.64 & 8.16 & 3093 & 2636 & 0.74 & 0.54 & 17.75 & 14.68 & 72.60 & 46.82 \\
\hline Zone 5 & 11.80 & 7.63 & 2916 & 2508 & 0.71 & 0.52 & 16.29 & 11.15 & 67.75 & 43.77 \\
\hline Zone 6 & 7.54 & 5.88 & 2165 & 1980 & 0.49 & 0.38 & 10.08 & 7.61 & 43.00 & 32.29 \\
\hline Zone 7 & 8.14 & 5.30 & 2377 & 2113 & 0.57 & 0.42 & 11.10 & 7.57 & 46.68 & 30.32 \\
\hline Zone 8 & 8.79 & 6.67 & 2206 & 2075 & 0.47 & 0.35 & 11.73 & 8.25 & 50.19 & 36.86 \\
\hline Zone 9 & 8.58 & 6.54 & 2195 & 2060 & 0.46 & 0.35 & 11.43 & 7.88 & 48.97 & 36.09 \\
\hline
\end{tabular}

${ }^{\mathrm{e}}$ Units for AC: $\mathrm{kmol}_{\mathrm{H}+\mathrm{eq}} / \mathrm{veh} \cdot \mathrm{km}, \mathrm{CC}: \mathrm{kg}_{\mathrm{CO} 2 \mathrm{eq}} / \mathrm{veh} \cdot \mathrm{km}, \mathrm{PM}$ : $\mathrm{kg}_{\mathrm{PM} 2.5 \mathrm{eq}} / \mathrm{veh} \cdot \mathrm{km}, \mathrm{PO}: \mathrm{kg}_{\mathrm{NMvOC}} / \mathrm{veh} \cdot \mathrm{km}, \mathrm{TE}$ : $\mathrm{kmol}_{\mathrm{Neq}} / \mathrm{veh} \cdot \mathrm{km}$.

The total impacts caused by each management zone in the four scenarios are shown in Figure 6 and in order to facilitate comparison between vehicle technologies, normalized impacts for the two policy-relevant scenarios (BAU, AQP) are included in Table 7. In the same line with the discussion of the previous section, it can be seen that the difference in the behaviors of the scenarios is caused by the amount of diesel vehicles in the fleet. In general, the impacts produced by zones 7 and 9 are the most considerable in terms of their absolute value, while zones 1, 2 and 4 have a marginal contribution. The distribution of the use-phase impacts according to the management zone can be seen in Figure 7. In both cases the share and the total impact of the zones is related to the total number of trips that occur at them, according to the traffic model of the Municipality of Madrid and the general composition of the vehicle fleet (Table 5).

These are necessary inputs that have to be fed to COPERT in order to quantify the emission factors that are used to build the respective inventories in SimaPro. In this case, zones 3, 5, 8 and 9 concentrate each more than 13\% of the total trips, while zones 1,2 and 4 accumulate a $7.5 \%$ share in total. Additionally, $24 \%$ of the trips in the city 
occur in zone 7, being the zone with the biggest share. From the mean speeds shown in Table 5, one can see that the highest amount of trips is concentrated in zones with high speed values. Due to the fact that speed is one of the critical parameters that COPERT uses to estimate emissions and considering the nature of the "speed-emission" curves that the software includes, one must expect higher impacts for vehicle types and technologies exhibiting the greatest emission factors at high speeds (Ntziachristos et al., 2009).
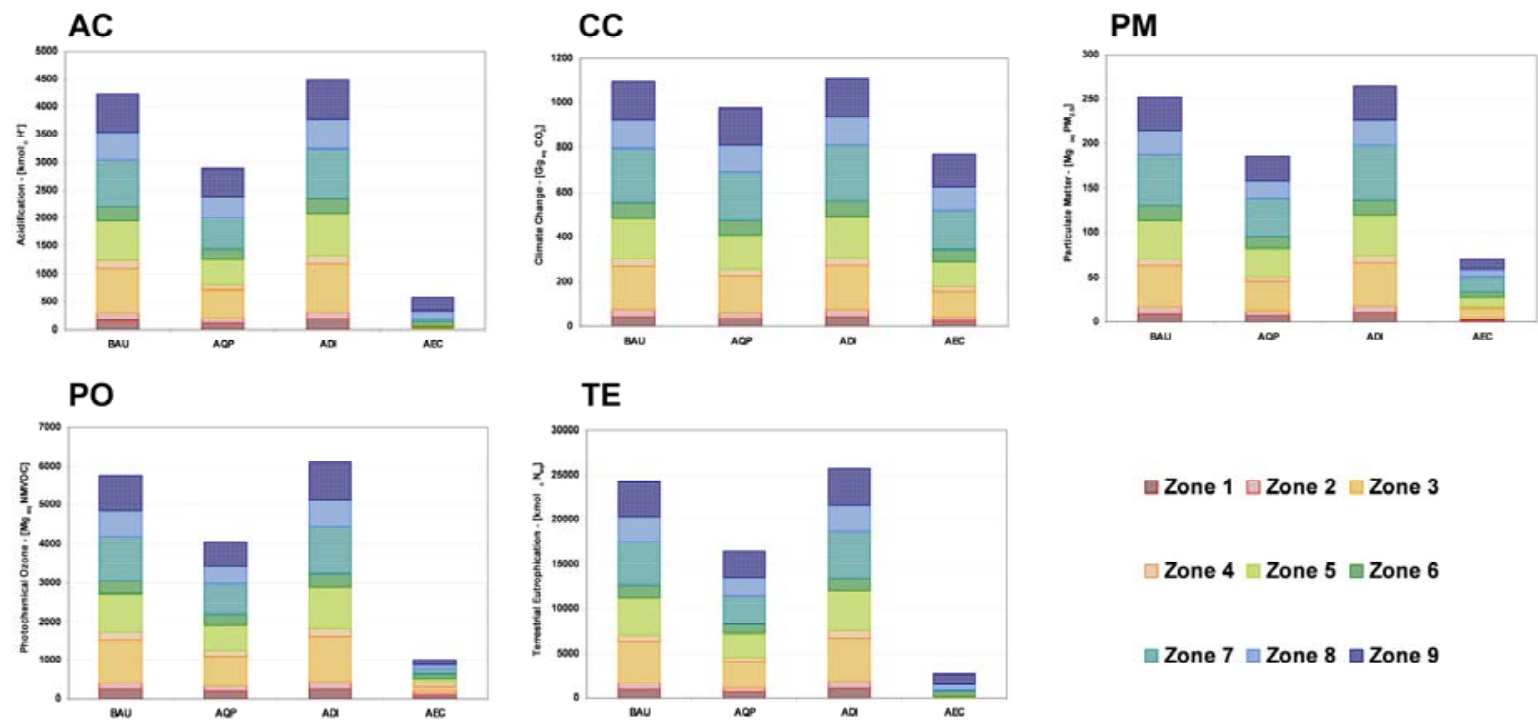

Figure 6. Comparison of absolute impacts produced by the vehicle use-phase (TtW) in the analyzed scenarios. AC: acidification. CC: climate change. PM: particulate matter. PO: photochemical ozone formation. TE: terrestrial eutrophication.

A central cause of this differences is also the fuel composition and consumption of each of the vehicle classes, which were assumed to comply with European regulations (i.e. sulfur contents $<10 \mathrm{ppm}$ ) (Leduc et al., 2010). The average consumptions of the considered vehicles circulating Madrid were $51.6 \mathrm{~g}_{\text {fuel }} / \mathrm{veh} \cdot \mathrm{km}$ for diesel vehicles (Euro 4,5), $53.3 \mathrm{~g}_{\text {fuel }} / \mathrm{veh} \cdot \mathrm{km}$ for LPG (Euro 4,5), $60 \mathrm{~g}_{\text {fuel }} / \mathrm{veh} \cdot \mathrm{km}$ for CNG (Euro 4,5) and 33 $g_{\text {fuel }} /$ veh·km for hybrid vehicles (Euro 4). From Figs. 6-7, it can be observed that slight variations exist between BAU, AQP and ADI, while the difference between these and 
AEC is greater. For $\mathrm{CC}$ there is a decrease in the share of zones 3,5 and 7 . The reduction in these zones is produced by the lower $\mathrm{CO}_{2}$ emission factors of hybrid

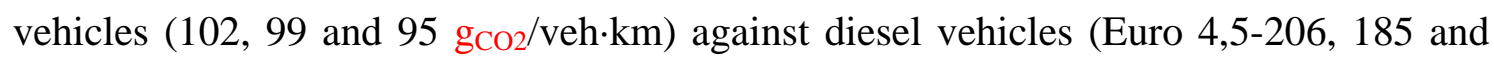
$\left.136 \mathrm{~g}_{\mathrm{CO} 2} / \mathrm{veh} \cdot \mathrm{km}\right)$. The use of LPG vehicles modestly contributes to the reduction, with emission factors of 189, 185 and $136 \mathrm{~g}_{\mathrm{CO} 2} / \mathrm{veh} \cdot \mathrm{km}$. Since these zones concentrate the largest number of annual trips (14.3\%, 14.1\% and 24.1\% respectively), reductions in the total impacts is experienced as a consequence of shifting to eco-friendly vehicles.

For AC and PO there is a dramatic decrease in the impacts when the fleet is completely made of ecologic vehicles for every zone in both, absolute value (Fig. 6) and relative share (Fig. 7). The cause of this is change is the overwhelming difference in emission factors for acidification-related compounds such as $\mathrm{NO}_{\mathrm{x}}$ and $\mathrm{SO}_{2}$. For example, the average zone-emission factor of hybrid vehicles for $\mathrm{NO}_{\mathrm{x}}$ is $0.012 \mathrm{~g}_{\mathrm{NOx}} / \mathrm{veh} \cdot \mathrm{km}$ against $0.566 \mathrm{~g}_{\mathrm{NOx}} / \mathrm{veh} \cdot \mathrm{km}$ (Euro 4) and $0.696 \mathrm{~g}_{\mathrm{NOx}} / \mathrm{veh} \cdot \mathrm{km}$ (Euro 5) for diesel cars. In the case of $\mathrm{SO}_{2}$, the emission of this pollutant by LPG and CNG-vehicles is nil, whereas the emission factor of diesel vehicles is $0.001 \mathrm{gso} / \mathrm{veh} \cdot \mathrm{km}$ (Euro 4,5). In the case of PM, the differences can also be explained by the values of the average emission factors of $\mathrm{PM}_{10}$ and $\mathrm{PM}_{2.5}$, namely 0.046 and $0.038 \mathrm{~g}_{\mathrm{PM}} / \mathrm{veh} \cdot \mathrm{km}$ respectively for diesel cars (Euro 4) and 0.016 and $0.009 \mathrm{~g}_{\mathrm{PM}} / \mathrm{veh} \cdot \mathrm{km}$ for hybrid cars. 


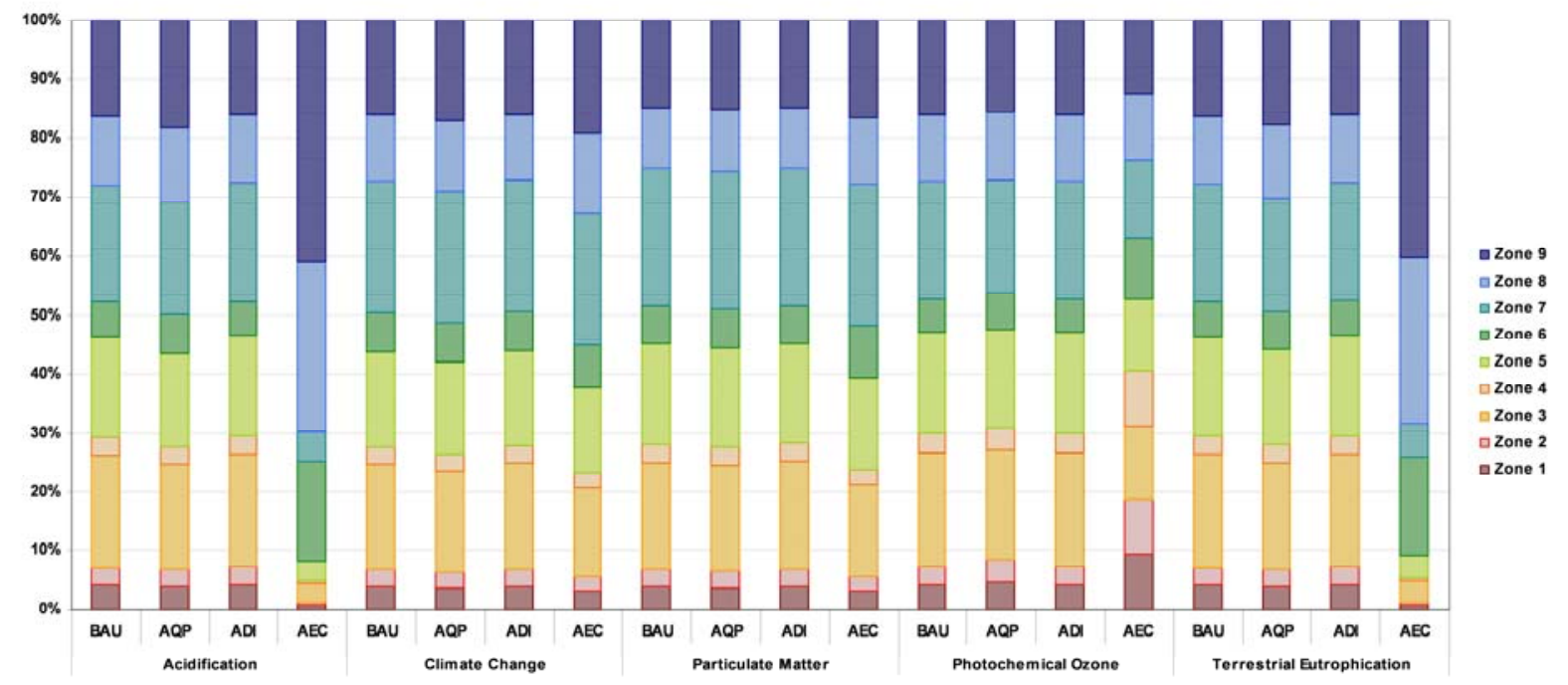

Figure 7. Comparison of the contribution of the considered management zones to the impacts produced by the studied scenarios (vehicle use-phase-TtW).

\subsection{Analysis of the air quality plan scenario}

The initial motivation of the initiative undertaken by the Municipality of Madrid was to comply with European $\mathrm{NO}_{2}$-regulations while keeping the efforts in reducing emissions of greenhouse gases. At this point, the analysis has made reference to ADI and AEC as opposite situations between which the initiative would materialize. However, in this section the analysis of the impacts produced by the vehicle fleet expected by the local authorities (AQP) will be carried out, as well as its comparison with BAU. The analysis will focus on the impacts produced by the most relevant pollutants addressed by the initiative $\left(\mathrm{CO}_{2}\right.$ and $\left.\mathrm{NO}_{\mathrm{x}}\right)$, namely $\mathrm{CC}$ and PO. Figure 8 and Figure 9 depict the resulting CC and PO impacts for BAU and AQP, which are divided by the total link length of the respective zone to eliminate the effects of the zone's size and the number of trips. 

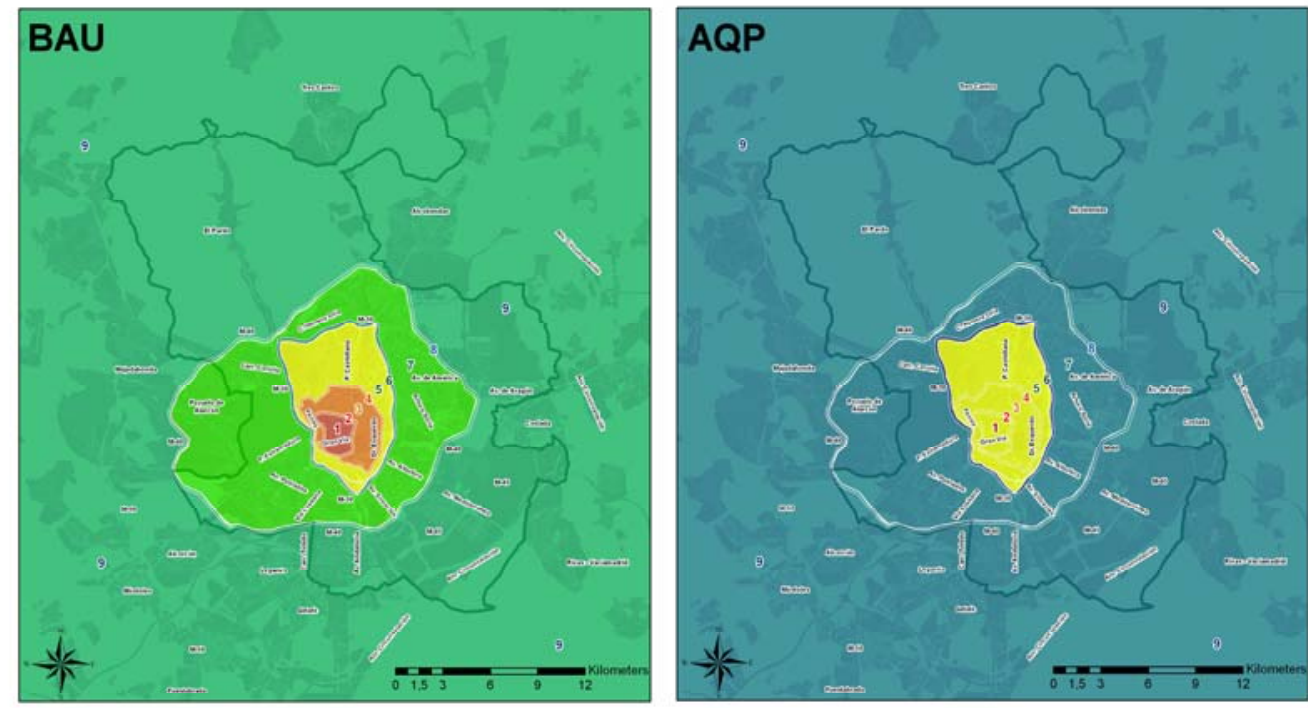

Impact per kilometer

$\left(\mathrm{kg}_{\mathrm{CO} 2} / \mathrm{km}\right)$

$0-1980$

$1981-2165$

$2166-2206$

$2207-2377$

$2378-2916$

$2917-3093$

$3094-3225$

$3226-3443$

Figure 8. Spatial representation of climate change impacts (CC) per kilometer of road length for BAU and AQP.

In the case of CC the adoption of the initiative, under the conditions of the AQP, results in a reduction for every management zone except zone 5 (Fig. 8). Reductions are deeper in zones 1, 2, 3 and 4, which are mainly caused by the lower emission factors that the ecologic vehicles present at lower speeds when compared to diesel vehicles. While the reduction is also evident for the rest of the zones, the central zones benefit more as a consequence of the moderation of high emissions associated to low speeds. As for PO, changes are witnessed in every zone and are especially important in zones 1, 2, 3, 4, 5 and 7 (Fig. 9). The cause of these deeper reductions in the central zones is the same than that observed for CC, namely the considerable difference of magnitude between the low-speed emission factors of typical diesel cars and ecologic cars. For example, Euro 4 diesel cars exhibited a $\mathrm{NO}_{\mathrm{x}}$ emission factor of $0.808 \mathrm{~g}_{\mathrm{NOx}} / \mathrm{veh} \cdot \mathrm{km}$ against 0.002 $\mathrm{g}_{\mathrm{NOx}} / \mathrm{veh} \cdot \mathrm{km}$ of hybrid vehicles at zone 1 (400 times lower). The same pattern is also observed, although moderately, for other PO-related pollutants such as CO. Interestingly, when the same analysis is carried out for NMVOC the emission factors are generally higher for ecologic cars than for diesel vehicles, being this especially true 
for hybrid vehicles $\left(0.34 \mathrm{~g}_{\mathrm{NMVOC}} / \mathrm{veh} \cdot \mathrm{km}\right.$ against $\left.0.03 \mathrm{~g}_{\mathrm{NMVOC}} / \mathrm{veh} \cdot \mathrm{km}\right)$. The resulting reductions are a consequence of the specific $\mathrm{NO}_{\mathrm{x}}, \mathrm{CO}$ and NMVOC rates that are considered by the calculation method of PO impacts in ILCD, the LOTOS-EUROS model for photochemical ozone, which seems to be more sensitive to $\mathrm{NO}_{\mathrm{x}}$ variations (van Zelm et al., 2008; Curier et al., 2012).

The spatial assessment of impacts is of special relevance for management practices, allowing the identification of specific regions of the city that are more sensitive to impacts under a wide range of perspectives (population, ecosystems, etc.). For example, the zones with the deepest reductions as a consequence of the AQP adoption (zones $1,2,3,4)$ also concentrate $18 \%$ of the city's population and $33 \%$ of the total economic activity (local GDP) (AM, 2010). To this respect, the direct quantification of the benefits that the adoption of the initiative brings to the local population is not straightforward and certainly outside the scope of the present work. However, the obtained results constitute a meaningful screening exercise which revealed that the implementation of the AQP does produce a favorable change in the associated environmental impacts when compared to a BAU scenario. 

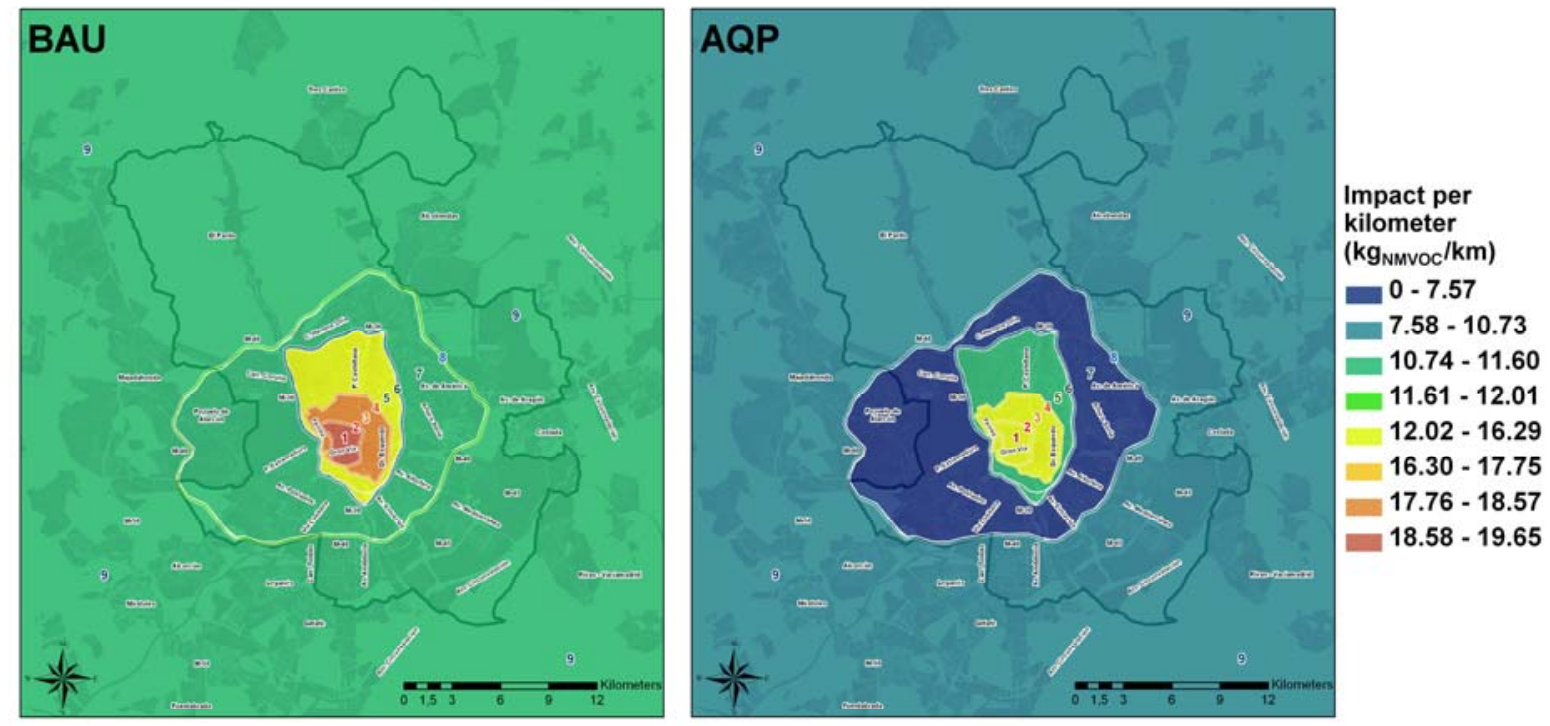

Figure 9. Spatial representation of photochemical ozone formation impacts (PO) per kilometer of road length for BAU and AQP.

\section{Conclusions}

A complete Life Cycle Analysis (LCA) of a series of scenarios that fit into the local air quality plan of the city of Madrid was performed regarding acidification, climate change, particulate matter, photochemical ozone formation and terrestrial eutrophication impacts. The objective of this analysis was not only to evaluate scenarios, but to link the evaluation with environmental management practices at the local level and to highlight the use of LCA as a policy-support tool. The election of the taxi sector as a suitable case study stemmed from the fact that it is public service operated as a concession and that is somehow illustrative of the local road-traffic sector. A special effort was made to collect specific information to accurately characterize each of the processes of the life cycle, aiming to provide results that are as representative of the local reality as possible in order to increase its applicability and use in policy-related activities. In the first place, the discussion focused on the different impacts caused during their complete life cycle for the four selected scenarios. Then, the analysis was taken to those phases that occur 
at the local scale (basically the vehicle use-phase), and are law subject of the Municipality of Madrid.

The analysis of the complete life cycle indicated that shifting from traditional diesel vehicles to ecologic alternatives (CNG, LPG and hybrid) reduced impacts associated with the vehicle use-phase, fuel refining and fuel transportation while it increases the share of the vehicle manufacturing stage. The general tendency observed, for the specific conditions of a taxi fleet in the city of Madrid was that using diesel vehicles has a deeper impact than an equivalent fleet of ecologic vehicles. When the discussion was placed at the local scale, the analysis revealed that the impacts produced by the taxi fleet are not only determined by the vehicle's fuel or technology, but by the specific conditions in which the vehicle circulates (i.e. speed) and on the traffic situation of the city, which determined the zonal distribution of trips. The analysis to the suitability of the local AQP by focusing on CC and PO impacts presented important reductions in the central zones of the city, as a consequence of a difference in emission factors that occur at low speeds. This analysis is likely of being complemented by an assessment of its economical viability, which is also a key issue to consider under a policy-support framework.

In general, what has been demonstrated in this work is that conducting a LCA intended for policy-support needs to be aware of the particularities of the system that is being studied because these provide enough guidance to identify accurate and appropriate courses of action. It should be noted that these results need to be complemented by considering all the factors that actually produce the shift from conventional vehicle technologies to “cleaner" alternatives in order to have a real policy-support tool. Although not studied under the scope of this paper, factors such as vehicle purchase, 
running and maintenance costs, refueling infrastructure, or brand appeal might influence the outcome of LCA studies. Despite these aforementioned, the nature of the obtained results and the conclusions drawn from it should encourage environmental stakeholders to rely on solid scientific tools in order to back-up the decision making process.

\section{Acknowledgements.}

The Municipality of Madrid provided the traffic model and data on the taxi fleet. The Spain's National Emission Inventory was made available by the Ministry of the Environment. Michel Vedrenne acknowledges financial support from UPM and CONACyT (Mexico).

\section{References}

Ayuntamiento de Madrid (AM), 2013. Memoria de Calidad del Aire del municipio de Madrid 2012.

Madrid, Spain. Available at: http://www.mambiente.munimadrid.es/opencms/export/sites/default/calaire/Anexos/MEMORIA_2012.pd f

Ayuntamiento de Madrid (AM), 2012. Madrid’s Air Quality Plan 2011-2015. General Directorate of Sustainability, Government Division of Environment, Safety and Mobility, Madrid City Council. Available online http://www.madrid.es/UnidadesDescentralizadas/Sostenibilidad/Otros/AirQualityPlan\%202011-15.pdf

Ayuntamiento de Madrid (AM), 2010. Anuario Estadístico de Ayuntamiento de Madrid 2009. Sección de $\begin{array}{llll}\text { Publicaciones. } & \text { Sadrid, } & \text { Available }\end{array}$ http://www.madrid.es/portales/munimadrid/es/Inicio/Ayuntamiento/Publicaciones 
Asociación Española de Fabricantes de Automóviles y Camiones (ANFAC), 2012. Memoria Anual 2012. Madrid, Spain. Available from: http://www.anfac.com/publicaciones.action.

Baptista, P.C., Silva, M.C., Farias, T.L., Heywood, J.B., 2012. Energy and environmental impacts of alternative pathways for the Portuguese road transportation sector. Energ. Policy 51, 802-815.

Baptista, P., Ribau, J., Bravo, J., Silva, C., Adcock, P., Kells, A., 2011. Fuel cell hybrid taxi life cycle analysis. Energ. Policy 39, 4683-4691.

Borge, R., Lumbreras, J., Pérez, J., de la Paz, D., Vedrenne, M., de Andrés, J.M., Rodríguez, M.E., 2014. Emission inventories and modeling requirements for the development of air quality plans. Application to Madrid (Spain). Sci. Tot. Env. 446-447, 809-819.

Borge, R., de Miguel, I., de la Paz, D., Lumbreras, J., Pérez, J., Rodríguez, M.E., 2012. Comparison of road traffic emission models in Madrid (Spain). Atmos. Environ. 62, 461-471.

Corporación de Reservas Estratégicas de Productos Petrolíferos (CORES), 2011. Boletín Estadístico de Hidrocarburos. Madrid, Spain.

Curier, R.L., Timmermans, R., Calabretta-Jongen, S., Eskes, H., Segers, A., Swart, D., Schaap, M., 2012. Improving ozone forecasts over Europe by synergistic use of the LOTOS-EUROS chemical transport model and in-situ measurements. Atmos. Environ. 60, 217-226.

DeCicco, J.M., 2013. Factoring the car-climate challenge: Insights and implications. Energ. Policy 59, 382-392.

European Comission (EC)-Institute for Environment and Sustainability, 2011. International Reference Life Cycle Data System (ILCD) Handbook- Recommendations for Life Cycle Impact Assessment in the European context. 1 ed. November 2011. EUR 24571 EN. Publications Office of the European Union. Luxemburg, Luxemburg. 
European Comission (EC), 2008. Directive 2008/50/EC of the European Parliament and of the Council of 21 May 2008 on ambient air quality and cleaner air for Europe. Official Journal L 152, 11.6. Available at: http://eur-lex.europa.eu

European Comission (EC), 2003. Reference Document on Best Available Techniques for Mineral Oil and Gas Refineries. Integrated Pollution Prevention and Control (IPPC). Available at: http://eippcb.jrc.ec.europa.eu/reference/BREF/ref_bref_0203.pdf

European Environment Agency (EEA). EMEP/EEA air pollutant emission inventory guidebook-2009. EEA Technical Report No. 9/2009. ISSN-1725-2237. Available at: http://www.eea.europa.eu/publications/emep-eea-emission-inventory-guidebook-2009.

Fontaras, G., Samaras, Z., 2010. On the way to $130 \mathrm{~g} \mathrm{CO} / \mathrm{km}$-Estimating the future characteristics of the average European passenger car. Energ. Policy 38, 1826-1833.

Frischknecht, R., Althaus, H.J., Doka, G., Dones, R., Heck, T., Hellweg, S., Hischier, R., Jungbluth, N., Nemecek, T., Rebitzer, G., Spielmann, M., 2004. Overview and Methodology. Final report Ecoinvent 2000 No.1, Swiss Centre for Life Cycle Inventories. Dübendorf, Switzerland.

Garg, A., Vishwanathan, S., Avashia, V., 2013. Life cycle greenhouse gas emission assessment of major petroleum oil products for transport and household sectors in India. Energ. Policy 58, 38-48.

Granovskii, M., Dincer, I., Rosen, M.A., 2006. Economic and environmental comparison of conventional, hybrid, electric and hydrogen fuel cell vehicles. J. Power Sources 159, 1186-1193.

Hackney, J., de Neufville, R., 2001. Life cycle model of alternative fuel vehicles: emissions, energy, and cost trade-offs. Transport. Res. D-Tr. E. 35, 243-266.

Hulskotte, J.H.J, Denier van der Gon, H.A.C., 2010. Fuel consumption and associated emissions from seagoing ships at berth derived from an on-board survey. Atmos. Environ. 44, 1229-1236 
International Association of Oil and Gas Producers (OGP), 2011. Environmental Performance in the E\&P Industry. 2010 Data. Report No. 466. October. London, United Kingdom. Available at: http://www.ogp.org.uk/pubs/466.pdf

International Energy Agency (IAE), 2012. 2012 Key World Energy Statistics. OECD/IEA. France. Available at: http://www.iea.org/publications

Janssens-Maenhout, G., Dentener, F., Van Aardenne, J., Monni, S., Pagliari, V., Orlandini, L., Klimont, Z., Kurokawa, J., Akimoto, H., Ohara, T., Wankmueller, R., Battye, B., Grano, D., Zuber, A., Keating, T., 2012. EDGAR-HTAP: a Harmonized Gridded Air Pollution Emission Dataset Based on National Inventories. European Commission Publications Office; 2012. JRC68434, EUR report No. EUR 25299. Ispra, Italy.

Jazcilevich, A.D., García Reynoso, A., Grutter, M., Delgado, J., Ayala, U.D., Suarez Lastra, M., Zuk, M., González Oropeza, R., Lents, J., Davis, N., 2011. An evaluation of the hybrid car technology for the Mexico Mega City. J. Power Sources 196, 5704-5718.

Kassomenos, P., Karakitsios, S., Papaloukas, C., 2006. Estimation of daily traffic emissions in a SouthEuropean urban agglomeration during a workday. Evaluation of several "what if” scenarios. Sci. Tot. Environ. 2-3, 480-490.

Klimont, Z., Streets, D.G., Gupta, S., Cofala, J., Lixin, F., Ichikawa, Y., 2002. Anthropogenic emissions of non-methane volatile organic compounds in China. Atmos. Environ. 36, 1309-1322.

Köhler, J., Schade, W., Leduc, G., Wiesenthal, T., Schade, B., Tercero Espinoza, L., 2013. Leaving fossil fuels behind? An innovation system analysis of low carbon cars. J. Clean. Prod. 48, 176-186.

Koroneos, C.J., Nanaki, E.A., 2007. Electric energy sustainability in the Eastern Balkans. Energ. Policy 35, 3826-3842.

Leduc, G., Mongelli, I., Uihlein, A., Nemry, F., 2010. How can our cars become less polluting? An assessment of the environmental improvement potential cars. Transp. Policy 17, 409-419. 
Libyan National Oil Corporation (NOC), 2012. Summary sheets of contract areas. Tripoli, Libya. Available at: http://www.temehu.com/oil-gas.htm

Lumbreras, J., Borge, R., Guijarro, A., López, J.M., Rodríguez, M.E., 2013. A methodology to compute emission projections from road transport (EmiTRANS). Technol. Forecast. Soc. http://dx.doi.org/10.1016/j.techfore.2013.02.011

Lukoil, 2012. Annual Report 2012. Moscow, Russia. Available from: http://www.lukoil.com/materials/doc/Annual_Report_2012

Ma, H., Balthasar, F., Tait, N., Riera-Palou, X., Harrison, A., 2012. A new comparison between the life cycle greenhouse gas emissions of battery electric vehicles and internal combustion vehicles. Energ. Policy 44, 160-173.

Menegaki, A.N., 2011. Bourgas-Alexandroupolis oil pipeline; will matching institutional and regulatory contexts lead to an effective bargaining and eventual consensus? Energ. Policy 39, 1277-1285.

Ministerio de Industria, Energía y Turismo (MINETUR), 2012. La Energía en España 2011. Subdirección General de Desarrollo Normativo, Informes y Publicaciones. Madrid, España.

Ministerio de Agricultura, Alimentación y Medio Ambiente (MAGRAMA), 2013. Sistema Español de Inventario (SEI). Madrid, Spain. Available at: http://www.magrama.gob.es/es/calidad-y-evaluacionambiental/temas/sistema-espanol-de-inventario-sei-/

Mourato, S., Saynor, B., Hart, D., 2004. Greening London's black cabs: a study of driver's preferences for fuel cell taxis. Energ. Policy 32, 685-695.

Nanaki, E.A., Koroneos, C.J., 2013. Comparative economic and environmental analysis of conventional, hybrid and electric vehicles-the case study of Greece. J. Clean. Prod. 53, 261-266. 
Ntziachristos, L., Gkatzoflias, D., Kouridis, C., Samaras, Z., 2009. COPERT: a European road transport emission inventory model. In: Athanasiadis, I.N., Mitkas, P.A., Rizzoli, A.E., Marx Gómez, J. (Eds.), Information Technologies in Environmental Engineering. Springer, 491-504.

Ntziachristos, L., Samaras, Z., 2001. An empirical method for predicting exhaust emissions of regulated pollutants from future vehicle technologies. Atmos. Environ. 35, 1985-1999.

Pérez, J., Lumbreras, J., López, J.M., García, J.A., Vedrenne, M., de Andrés, J.M., de la Paz, D., 2012. Comparison of greenhouse gas emissions from different vehicles covering the entire life cycle. WIT Transactions on the Built Environment 128, 85-95.

Petróleos Mexicanos (Pemex), 2013. Indicadores Petroleros 2013. Informe mensual sobre producción y comercio de hidrocarburos. Subdirección de Planeación Económica. Mexico City, Mexico. Available at: http://www.ri.pemex.com/files/dcpe/petro/indicador.pdf

Pollet, B.G., Staffell, I., Shang, J.L., 2012. Current status of hybrid, battery and fuel cell electric vehicles: From electrochemistry to market prospects. Review. Electrochim. Acta 84, 235-249.

Propfe, B., Kreyenberg, D., Wind, J., Schmid, S., 2013. Market penetration analysis of electric vehicles in the German passenger car market towards 2030. Int. J. Hydrogen Energ. 38, 5201-5208.

Puertos del Estado, 2011. Anuario Estadístico 2011. Ministerio de Fomento. Madrid, Spain. Available at: http://www.puertos.es/estadisticas/anuarios_de_puertos/index.html

Repsol, 2012. Informe Anual-Repsol 2012. Madrid, Spain. Available at: http://www.repsol.com/es_es/corporacion/accionistas-inversores

Romm, J., 2006. The car and fuel of the future. Energ. Policy 34, 2609-2614.

Saudi-Aramco, 2013. Shaping tomorrow: 2012 Annual Review. Dhahran, Kingdom of Saudi Arabia. Available at: http://www.saudiaramco.com/content/dam/Publications 
Seckin, C., Sciubba, E., Bayulken, A.R., 2013. Extended exergy analysis of Turkish transportation sector. J. Clean. Prod. 47, 422-436.

Société Nationale pour la Recherche, la Production, le Transport, la Transformation, et la Commercialisation des Hydrocarbures (Sonatrach), 2013. Sonatrach: an integrated oil \& gas company. Algiers, Algeria. Available at: http://www.sonatrach.com/rapport-annuel.html

Spielmann, M., Althaus, H.J., 2007. Can a prolonged use of a passenger car reduce environmental burdens? Life Cycle analysis of Swiss passenger cars. J. Clean. Prod. 15, 1122-1134.

Statoil, 2012. 2012 Annual Reporting Compendium. Stavanger, Norway. Available at: http://www.statoil.com/AnnualReport2012

Thabrew, L., Wiek, A., Ries, R., 2009. Environmental decision making in multi-stakeholder contexts: applicability of life cycle thinking in development planning and implementation. J. Clean. Prod. 17, 6776.

Total-E\&P Congo, 2008. Moho-Bilondo: a first in Congo’s deep offshore. Paris, France. Available at: http://www.total.com/en/our-energies/oil/exploration-and-production/projects-and-achievements

Total-E\&P Sonangol, 2005. Dalia: the conquest of the deep offshore. Paris, France. Available at: http://www.total.com/en/our-energies/oil/exploration-and-production/projects-and-achievements

Tzamkiozis, T., Ntziachristos, L., Samaras, Z., 2010. Diesel passenger car PM emissions: From Euro 1 to Euro 4 with particle filter. Atmos. Environ. 44, 909-916.

van Vliet, O.P.R., Kruithof, T., Turkenburg, W.C., Faaij, A.P.C., 2010. Techno-economic comparison of series hybrid, plug-in hybrid, fuel cell and regular cars. . J. Power Sources 195, 6570-6585.

van Zelm, R., Huijbregts, M.A.J., Den Hollander, H.A., Van Jaarsveld, H.A., Sauter, F.J., Struijs, J., Van Wijnen, H.J., Van de Meent, D., 2008. European characterization factors for human health damage of $\mathrm{PM}_{10}$ and ozone in life cycle impact assessment. Atmos. Environ. 42, 441-453. 
Vedrenne, M., Borge, R., de la Paz, D., Lumbreras, J., Rodríguez, M.E., 2011. Comparison and assessment of two emission inventories for the Madrid region. WIT Transactions on Ecology and the Environment 157, 81-92.

Volvo Truck Corporation (VTC), 2003. Emissions from Volvo’s trucks (standard diesel fuel). PM report No. 20640/03-017. November. Stockholm, Sweden. 